\title{
A Foliar Blight and Tuber Rot of Potato Caused by Phytophthora nicotianae: New Occurrences and Characterization of Isolates
}

\author{
Raymond J. Taylor and Julie S. Pasche, Department of Plant Pathology, North Dakota State University, Fargo \\ 58105; Courtney A. Gallup and H. David Shew, Department of Plant Pathology, North Carolina State University, \\ Raleigh 27695; and Neil C. Gudmestad, Department of Plant Pathology, North Dakota State University, Fargo
}

\begin{abstract}
Taylor, R. J., Pasche, J. S., Gallup, C. A., Shew, H. D., and Gudmestad, N. C. 2008. A foliar blight and tuber rot of potato caused by Phytophthora nicotianae: New occurrences and characterization of isolates. Plant Dis. 92:492-503.

Phytophthora spp. are pathogenic to many plant species worldwide, and late blight, caused by Phytophthora infestans, and pink rot, caused by P. erythroseptica, are two important diseases of potato. Another Phytophthora sp., P. nicotianae, was recovered from pink-rot-symptomatic tubers collected from commercial fields in Nebraska, Florida, and Missouri in 2005, 2006, and 2007, respectively. P. nicotianae also was recovered from foliage obtained from commercial potato fields in Nebraska and Texas exhibiting symptoms very similar to those of late blight. Isolates of $P$. cactorum also were recovered from foliar infections in a commercial potato field in Minnesota in 2005. Natural infection of potato foliage by P. cactorum and infection of wounded potato tuber tissue via inoculation with zoospores of $P$. capsici are reported here for the first time. Isolates of $P$. nicotianae, regardless of origin, were primarily of the A1 mating type. All isolates of $P$. nicotianae and $P$. cactorum were sensitive to the fungicide mefenoxam. Optimum growth of $P$. nicotianae, $P$. erythroseptica, and $P$. cactorum in vitro occurred at $25^{\circ} \mathrm{C}$; however, only $P$. nicotianae sustained growth at $35^{\circ} \mathrm{C}$. Regardless of the tissue of origin, all isolates of $P$. nicotianae and $P$. cactorum were capable of infecting potato tubers and leaves. However, isolates of $P$. nicotianae were less aggressive than P. erythroseptica isolates only when tubers were not wounded prior to inoculation. Pink rot incidence varied significantly among potato cultivars following inoculation of nonwounded tubers with zoospores of P. nicotianae, ranging from $51 \%$ in Red Norland to $19 \%$ in Atlantic. Phytophthora spp. also differed significantly in their ability to infect potato leaves. Highest infection frequencies were obtained with $P$. infestans and levels of infection varied significantly among $P$. nicotianae isolates. The rate of foliar lesion expansion was similar among isolates of $P$. nicotianae and $P$. infestans. Whereas $P$. infestans infections yielded profuse sporulation, no sporulation was observed with foliar infections of $P$. nicotianae.
\end{abstract}

Additional keywords: Solanum tuberosum, water rot

A number of plant pathogens cause foliar diseases of potato (Solanum tuberosum). Brown spot, caused by Alternaria alternata (4), and early blight, caused by A. solani (9), occur worldwide and generally are associated with senescing foliage on early-maturing cultivars. Colletotrichum coccodes also is capable of infecting potato foliage and reducing yield $(13,14)$. Perhaps the most well-known foliar disease of potato is late blight, caused by Phytophthora infestans (10). P. infestans is the type species of the genus Phytophthora and may be the most impor-

Corresponding author: N. C. Gudmestad

E-mail: Neil.Gudmestad@ndsu.edu

Accepted for publication 5 December 2007.

doi:10.1094/PDIS-92-4-0492

(C) 2008 The American Phytopathological Society tant disease of potato. All of the abovementioned foliar pathogens also can infect tubers, causing various rots or blemishes.

Other Phytophthora spp. also infect potato tubers. P. erythroseptica is the primary pathogen causing pink rot (15). Pink rot is an important soilborne "water rot" of potato tubers in the United States (25) and most potato-growing regions throughout the world $(15,28)$. As the name implies, the diagnostic characteristic of this disease is a watery, pink discoloration of infected tissue that develops and intensifies after exposure to the air for a short period of time (11). Pink rot first was described as a potato tuber disease in Ireland (21) and subsequently was reported in North America (1). Although P. erythroseptica is the principal pathogen associated with the disease, several other Phytophthora spp. have been reported to produce pink rot symptoms (8). Species isolated from infected tubers include $P$. drechsleri (6), P. megasperma (2),
P. cryptogea $(12,16,22)$, and $P$. nicotianae $(12,18)$. Prior to the latter reports, $P$. nicotianae ( synonym $=P$. parasitica) had not been isolated from naturally infected potato tissue but was shown to be able to cause both tuber rot and foliar and stem blights by artificial inoculation under controlled environments (8). Although it has an extensive and diverse host range including over 300 plant species, P. nicotianae has not been considered to be a significant potato pathogen. Results obtained in a multiyear survey consisting of 2,277 potato tubers with water rot symptoms collected from 16 states and $2 \mathrm{Ca}$ nadian provinces support the view that $P$. erythroseptica is the primary pathogen responsible for causing pink rot in North America (31).

During extensive travels to many potato production areas in the United States, one of the authors (N. C. Gudmestad) has encountered late-blight-like symptoms on the foliage in a number of potato fields. The symptoms vary but lesions generally are roughly circular in shape, surrounded by a light-green or chlorotic halo (Fig. 1A). In some instances, the lesions extend into the petiole and stem, causing lesions similar to the newer immigrant genotypes of $P$. infestans (Fig. 1B). Unlike typical late blight, foliar lesions of the disease lacked the "downy mildew" appearance characteristic of late blight. However, under environmental conditions conducive to disease development, large areas of potato fields can be affected (Fig. 1C), with stems becoming girdled and plants completely defoliated (Fig. 1D). Our research group has undertaken studies to determine the cause of this disease.

This article reports the occurrence of $P$. nicotianae isolates capable of causing foliar symptoms similar to late blight caused by $P$. infestans as well as tuber rot symptoms typical of $P$. erythrosepticainduced pink rot. In contrast to $P$. erythroseptica infections, tuber tissue infected by $P$. nicotianae generally becomes tan to brown in color when exposed to air, and the intensity of the infection varies with cultivar. Additionally, aggressiveness of $P$. nicotianae isolates was compared with other Phytophthora spp. when inoculated 
onto tubers and leaves of commonly grown potato cultivars.

\section{MATERIALS AND METHODS}

Isolate collection. Isolates evaluated in this study were obtained from naturally occurring field infections (Table 1) by transferring small pieces of infected potato leaf or tuber tissue, approximately $25 \mathrm{~mm}^{3}$ in size, to culture dishes containing water agar. Following incubation in the dark at 17 to $20^{\circ} \mathrm{C}$ for 3 to 5 days, colonies with mycelia resembling that of Phytophthora spp. were selected and isolated utilizing hyphal tip methods.

Morphological characterization. Cultures were grown on 5\% clarified carrot agar (CA) $(50 \mathrm{ml}$ of Hollywood carrot juice, $950 \mathrm{ml}$ of deionized water, and $20 \mathrm{~g}$ of Difco Bacto agar) and maintained with regular transfers. Vegetative and reproduc- tive stages were examined in cultures grown for 1 to 4 weeks at 20 to $25^{\circ} \mathrm{C}$ in light using a Nikon TMS Inverted Phase Contrast Microscope. Isolates were scored for appearance of hyphae, size and shape of sporangia and chlamydospores, and presence or absence of oospores. Observations were compared to published descriptions for Phytophthora spp. (8).

DNA extraction. Agar plugs were placed in 25-ml sterile pea broth and allowed to grow for 7 days. Pea broth was prepared by autoclaving $120 \mathrm{~g}$ of frozen store-bought peas in 1 liter of deionized water for $5 \mathrm{~min}$. The broth was filtered through a double layer of cheese cloth and then sterilized by autoclaving for $30 \mathrm{~min}$. After 7 days of growth at 20 to $24^{\circ} \mathrm{C}$, mycelium was vacuum filtrated, rinsed with sterile deionized water, and lyophilized. DNA was extracted from frozen mycelia using a cetyl trimethyl ammonium bromide (CTAB) procedure. Samples were ground in liquid nitrogen, and genomic DNA was isolated by suspending the mycelial powder in $500 \mu \mathrm{l}$ of CTAB. Samples were incubated at $65^{\circ} \mathrm{C}$ for $60 \mathrm{~min}$; then, $500 \mu \mathrm{l}$ of phenol-chloroform-isoamyl alcohol $(25: 24: 1)$ was added. Samples were shaken gently for $10 \mathrm{~min}$, then centrifuged at $13,000 \times g$ for $15 \mathrm{~min}$. The upper aqueous phase was transferred to a clean microcentrifuge tube before the phenolchloroform-isoamyl alcohol and centrifugation steps were repeated. After the upper aqueous phase was collected a second time, $50 \mu$ of RNAse A was added, and samples were incubated at $37^{\circ} \mathrm{C}$ for 30 min. The phenol-chloroform-isoamyl alcohol and centrifugation steps were repeated a third time using only $250 \mu \mathrm{l}$ of phenolchloroform-isoamyl alcohol. After collect-

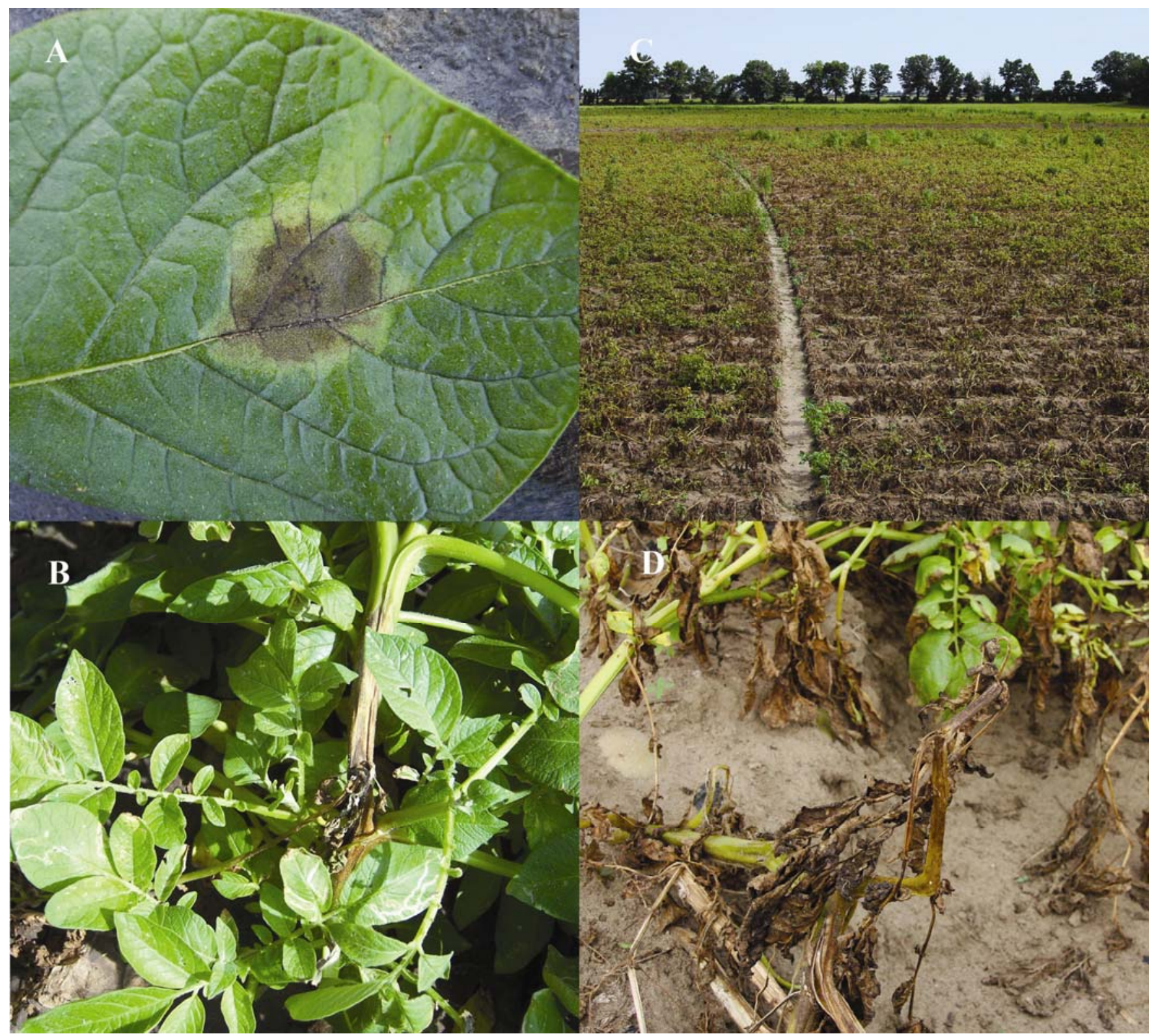

Fig. 1. Symptoms of naturally occurring Phytophthora nicotianae infections of A, potato leaf tissue, $\mathbf{B}$, stem tissue, $\mathbf{C}$, infection in a commercial potato field, and $\mathbf{D}$, complete defoliation of a plant. 
ing the upper aqueous suspension a third time, an equal volume of $95 \% \mathrm{EtOH}$ was added. The samples were incubated at $4{ }^{\circ} \mathrm{C}$ overnight. DNA precipitate was collected by centrifugation at $13,000 \times g$ for $5 \mathrm{~min}$. The supernatant was discarded, and the pellets were washed with $100 \mu \mathrm{l}$ of cold $80 \% \mathrm{EtOH}$ for $5 \mathrm{~min}$. The pellets were allowed to dry completely and DNA was suspended in $30 \mu \mathrm{l}$ of nuclease-free water and stored at $4{ }^{\circ} \mathrm{C}$. Extracted DNA was electrophoresed in a $1 \%$ agarose gel to confirm the quality of the DNA. DNA concentrations were determined using a NanoDrop 1000. DNA was diluted to 10 $\mathrm{ng} / \mu \mathrm{l}$ for subsequent use in polymerase chain reaction (PCR).

PCR amplification. DNA samples were amplified using species-specific primers previously described for P. nicotianae (7). Primer no. 1 (5'-CTGACGATCCAGATC CTCTGCACG- $3^{\prime}$ ) was used as the forward primer and primer no. 2 (5'-CTTGCGAGG CTTGACCGCTTCCTA-3') was used as the reverse primer. Amplification reactions were done in 25- $\mu \mathrm{l}$ reactions using an Eppendorf Mastercycler Thermalcycler (Eppendorf Scientific, Westbury, NY). Each reaction tube contained $2 \mu \mathrm{l}$ of $10 \mathrm{ng} / \mu \mathrm{l}$ template DNA, $19 \mu \mathrm{l}$ of sterile nucleasefree water, $0.25 \mu \mathrm{l}$ each of $10 \mu \mathrm{M}(2.5 \mu \mathrm{M})$ forward and reverse primers, $2.5 \mu \mathrm{l}$ of $10 \mathrm{x}$ PCR buffer, $50 \mu \mathrm{M}$ each dNTP, and 2.5 units $(0.5 \mu \mathrm{l})$ of Taq DNA polymerase (Qiagen). The thermal cycling parameters were one cycle at $94^{\circ} \mathrm{C}$ for one min; 30

Table 1. Identity, source, mating type, and mefenoxam sensitivity of Phytophthora spp. isolates

\begin{tabular}{|c|c|c|c|c|c|c|c|}
\hline Isolate & $\begin{array}{c}\text { State of } \\
\text { origin }\end{array}$ & $\begin{array}{l}\text { Source } \\
\text { tissue }\end{array}$ & $\begin{array}{c}\text { Mating } \\
\text { type }^{\mathrm{a}}\end{array}$ & $\underset{(\mu \mathrm{g} / \mathrm{ml})^{\mathbf{b}}}{\mathbf{E C}_{50}}$ & $\begin{array}{c}\text { Growth temperature } \\
\text { experiments }\end{array}$ & $\begin{array}{c}\text { Preliminary } \\
\text { pathogenicity } \\
\text { experiments }\end{array}$ & $\begin{array}{c}\text { Tuber and foliar } \\
\text { cultivar susceptibility } \\
\text { experiments }\end{array}$ \\
\hline \multicolumn{8}{|c|}{ Phytophthora erythroseptica } \\
\hline $266-2$ & Washington & Potato tuber & SF & 0.02 & $\mathrm{X}$ & $\mathrm{X}$ & $\mathrm{X}$ \\
\hline $364-5$ & Minnesota & Potato tuber & SF & 0.04 & $\mathrm{X}$ & $\mathrm{X}$ & $\mathrm{X}$ \\
\hline 05NE1-3 & Nebraska & Potato tuber & SF & 0.04 & $\mathrm{X}$ & $\ldots$ & $\ldots$ \\
\hline$E 7^{\mathrm{c}}$ & Maine & Potato tuber & SF & 0.07 & $\mathrm{X}$ & $\ldots$ & $\ldots$ \\
\hline $06 \mathrm{CO} 1-2$ & Colorado & Potato tuber & SF & 0.08 & $\mathrm{X}$ & $\ldots$ & $\ldots$ \\
\hline PE-89 & Maine & Potato tuber & SF & $>100$ & $\mathrm{X}$ & $\ldots$ & $\ldots$ \\
\hline $217-1$ & Idaho & Potato tuber & SF & $>100$ & $\mathrm{X}$ & $\ldots$ & $\ldots$ \\
\hline $05 \mathrm{MN} 7-2$ & Minnesota & Potato tuber & SF & $>100$ & $\mathrm{X}$ & $\ldots$ & $\ldots$ \\
\hline 06NE2-1 & Nebraska & Potato tuber & SF & $>100$ & $\mathrm{X}$ & $\ldots$ & $\ldots$ \\
\hline $06 \mathrm{CO} 1-1$ & Colorado & Potato tuber & SF & $>100$ & $\mathrm{X}$ & $\ldots$ & $\ldots$ \\
\hline \multicolumn{8}{|l|}{ P. nicotianae } \\
\hline 05NE1-1 & Nebraska & Potato tuber & A2 & 0.13 & $\ldots$ & $\mathrm{X}$ & $\mathrm{X}$ \\
\hline 05NE1-2 & Nebraska & Potato tuber & A2 & 0.09 & $\mathrm{X}$ & $\ldots$ & $\mathrm{X}$ \\
\hline 06NE1-1 & Nebraska & potato leaf & A2 & 0.18 & $\ldots$ & $\ldots$ & $\ldots$ \\
\hline 06NE1-5 & Nebraska & Potato leaf & A1 & 0.09 & $\mathrm{X}$ & $\ldots$ & $\ldots$ \\
\hline 06FL1-7 & Florida & Potato tuber & A1 & 0.24 & $\mathrm{X}$ & $\mathrm{X}$ & $\ldots$ \\
\hline $06 \mathrm{FL} 1-8$ & Florida & Potato tuber & A1 & 0.15 & $\ldots$ & $\ldots$ & $\ldots$ \\
\hline 06FL1-9 & Florida & Potato tuber & A1 & 0.25 & $\mathrm{X}$ & $\ldots$ & $\ldots$ \\
\hline $\mathrm{N} 3^{\mathrm{c}}$ & Delaware & Potato tuber & A1 & 0.32 & $\ldots$ & $\mathrm{X}$ & $\mathrm{X}$ \\
\hline $\mathrm{N} 5^{\mathrm{c}}$ & Delaware & Potato tuber & A1 & 0.29 & $\ldots$ & $\ldots$ & $\mathrm{X}$ \\
\hline 06TX1-1 & Texas & Potato leaf & $\mathrm{A} 1 / \mathrm{A} 2$ & 0.12 & . & $\ldots$ & $\ldots$ \\
\hline $06 \mathrm{TX} 1-3$ & Texas & Potato leaf & $\mathrm{A} 1$ & 0.14 & $\mathrm{X}$ & $\mathrm{X}$ & $\mathrm{X}$ \\
\hline 06TX1-4 & Texas & Potato leaf & A1 & 0.14 & $\ldots$ & $\ldots$ & $\ldots$ \\
\hline $06 \mathrm{TX} 1-5$ & Texas & Potato leaf & A1 & 0.08 & $\ldots$ & $\ldots$ & $\ldots$ \\
\hline 06TX1-6 & Texas & Potato leaf & A1 & 0.08 & $\mathrm{X}$ & $\ldots$ & $X$ \\
\hline 07TX1-1 & Texas & Potato leaf & A1 & 0.08 & $\mathrm{X}$ & $\ldots$ & $\ldots$ \\
\hline $07 \mathrm{TX} 1-2$ & Texas & Potato leaf & A1 & 0.12 & $\ldots$ & $\ldots$ & $\ldots$ \\
\hline 07TX1-3 & Texas & Potato leaf & A1 & 0.36 & $\ldots$ & $\ldots$ & $\ldots$ \\
\hline 07TX1-4 & Texas & Potato leaf & A1 & 0.10 & $\ldots$ & $\ldots$ & $\ldots$ \\
\hline $07 \mathrm{TX} 1-5$ & Texas & Potato leaf & A1 & 0.12 & $\ldots$ & $\ldots$ & $\ldots$ \\
\hline 07TX1-6 & Texas & Potato leaf & A1 & 0.07 & $\ldots$ & $\ldots$ & $\ldots$ \\
\hline 07TX1-7 & Texas & Potato leaf & A1 & 0.09 & $\ldots$ & $\ldots$ & $\ldots$ \\
\hline $07 \mathrm{TX} 1-8$ & Texas & Potato leaf & $\mathrm{A} 1$ & 0.09 & $\ldots$ & $\ldots$ & $\ldots$ \\
\hline 07TX1-9 & Texas & Potato leaf & A1 & 0.39 & $\ldots$ & $\ldots$ & $\ldots$ \\
\hline $07 T X 2-1$ & Texas & Potato leaf & $\mathrm{A} 1$ & 0.42 & $\ldots$ & $\ldots$ & $\ldots$ \\
\hline $07 \mathrm{TX} 2-2$ & Texas & Potato petiole & A1 & 0.32 & $\mathrm{X}$ & $\ldots$ & $\ldots$ \\
\hline 07MO1-1 & Missouri & Potato tuber & A1 & 0.37 & $X$ & $\ldots$ & $\ldots$ \\
\hline 07MO1-2 & Missouri & Potato tuber & A1 & 0.07 & $\mathrm{X}$ & $\ldots$ & $\ldots$ \\
\hline $07 \mathrm{MO} 1-3$ & Missouri & Potato tuber & A1 & 0.07 & $\mathrm{X}$ & $\ldots$ & $\ldots$ \\
\hline 07MO1-4 & Missouri & Potato tuber & A1 & 0.07 & $\ldots$ & $\ldots$ & $\ldots$ \\
\hline 07MO1-5 & Missouri & Potato tuber & A1 & 0.07 & $\ldots$ & $\ldots$ & $\ldots$ \\
\hline $07 \mathrm{MO} 1-6$ & Missouri & Potato tuber & A1 & 0.07 & $\ldots$ & $\ldots$ & $\ldots$ \\
\hline 07MO1-7 & Missouri & Potato tuber & A0 & 0.09 & $\ldots$ & $\ldots$ & $\ldots$ \\
\hline \multicolumn{8}{|l|}{ P. cactorum } \\
\hline 05MN55-1 & Minnesota & Potato leaf & SF & 0.05 & $\mathrm{X}$ & $\ldots$ & $\mathrm{X}$ \\
\hline $05 \mathrm{MN} 55-2^{\mathrm{d}}$ & Minnesota & Potato leaf & NT & 0.05 & $X$ & $\ldots$ & $\mathrm{X}$ \\
\hline $05 \mathrm{MN} 55-3^{\mathrm{d}}$ & Minnesota & Potato leaf & NT & 0.06 & $\ldots$ & $\ldots$ & $\mathrm{X}$ \\
\hline \multicolumn{8}{|l|}{ P. capsici } \\
\hline $\mathrm{C} 19^{\mathrm{c}}$ & Delaware & Unknown & NT & 83.5 & $\ldots$ & $\ldots$ & $\mathrm{X}$ \\
\hline \multicolumn{8}{|l|}{$P$. infestans } \\
\hline $02-007-1^{\mathrm{e}}$ & Michigan & Potato leaf & A2 & NT & $\ldots$ & $\ldots$ & $X$ \\
\hline $02-007-2^{\mathrm{e}}$ & Michigan & Potato leaf & A2 & NT & $\ldots$ & $\ldots$ & $\mathrm{X}$ \\
\hline
\end{tabular}

${ }^{\text {a }} \mathrm{SF}=$ self fertile/homothallic, $\mathrm{AO}=$ oospores not produced with either $\mathrm{A} 1$ or $\mathrm{A} 2$ tester isolates, and $\mathrm{NT}=$ not tested.

${ }^{\mathrm{b}} \mathrm{EC}_{50}=$ concentration resulting in $50 \%$ reduction of mycelial growth.

${ }^{\mathrm{c}}$ From the collection of Robert Mulrooney, University of Delaware.

${ }^{\mathrm{d}}$ Isolate identification based upon morphological and physiological characteristics only.

e From the collection of William Kirk, Michigan State University. 
cycles of 2 min of annealing at $65^{\circ} \mathrm{C}, 3$ min of extension at $72^{\circ} \mathrm{C}$, and $1 \mathrm{~min}$ of denaturation at $94^{\circ} \mathrm{C}$; followed by one extension cycle at $72^{\circ} \mathrm{C}$ for $10 \mathrm{~min}$. A negative control (without template DNA) was included in the amplification to ensure that the reagents were not contaminated. Following amplification, the amplicons were visualized on a $1 \%$ agarose gel and photographed under shortwave UV using the UVP BioDoc-It System.

DNA from each isolate also was amplified using universal internal transcribed spacer (ITS) primers for the purpose of sequencing for species determination. Protocols, primers, and reaction conditions were those described in detail for the identification of plant-pathogenic Phytophthora spp. (http://www.phytid.org/methods.htm). After amplification, the amplicons were visualized on a $1 \%$ agarose gel to check DNA concentration and purity. However, instead of fingerprinting, as described in the website, PCR products were purified using the QIAquick PCR Purification Kit Protocol (QIAquick Gel Extraction Kit; Qiagen). Purified PCR products then were sent to the DNA Sequencing and Genotyping facility in the Life Sciences Core Laboratory Center at Cornell University for sequencing. The same primers were used for sequencing as those used for amplification.

Mating type. The mating type of $P$. nicotianae isolates was determined by pairing each isolate with a known A1 and a known A2 isolate. The known mating types were isolates of $P$. nicotianae recovered from tobacco fields in 2006 from Surry County (A1) and Duplin County (A2), NC. Isolates were paired on CA supplemented with water-soluble cholesterol at $5 \mathrm{ppm}$ and then incubated in the dark for 21 days at 20 to $24^{\circ} \mathrm{C}$. Each pairing was observed microscopically for the presence of oospores. If oospores formed when paired with the known A1, the isolate was considered to be an A2 mating type, and vice versa. Isolates that formed oospores with both testers were scored as A1/A2 and isolates that failed to form oospores with either isolate were designated AO.

Reference isolates of Phytophthora spp. Isolates of $P$. nicotianae (N3 and N5), and $P$. capsici $(\mathrm{C} 19)$ received from the collection of Robert Mulrooney, University of Delaware, and $P$. infestans isolates 02007-1 and 02-007-2 obtained from William Kirk, Michigan State University, were included in the inoculation studies as reference controls for comparison (Table 1). Isolates of $P$. infestans were maintained on rye $B$ medium and all other isolates were maintained on clarified $10 \%$ V8 juice agar medium (CV8; $100 \mathrm{ml}$ of clarified V8 juice, $15 \mathrm{~g}$ of agar, and $900 \mathrm{ml}$ of deionized $\mathrm{H}_{2} \mathrm{O}$ ) in the dark at $20 \pm 1^{\circ} \mathrm{C}$ prior to testing. Isolates of $P$. erythroseptica used in these experiments were obtained from an extensive culture collection held by the authors at North Dakota State University (Table 1). All isolates were held in longterm storage and grown as previously described $(23,24,29-32)$.

Mefenoxam sensitivity. Mefenoxam (Ridomil Gold 4EC; Syngenta Crop Protection, Greensboro, NC) sensitivity of the isolates was determined using an in vitro screening method similar to a technique described previously (29-31). Tests were conducted on modified V8 juice agar $(5 \%$ V8 juice filtered through four layers of cheesecloth and 2\% agar) amended with fungicide in a 10-fold dilution series ranging from 0.01 to $100 \mu \mathrm{g} / \mathrm{ml}$. Plates not amended with mefenoxam served as controls. A cork borer was used to excise 5mm-diameter disks containing mycelium and agar from the margin of actively growing colonies of 4- to 6-day-old cultures. Each disk was positioned in the center of a 9-cm culture dish with the mycelium in contact with the test medium. The dishes contained $17 \mathrm{ml}$ of either amended or nonamended medium and testing was performed in duplicate at each concentration.

Isolate growth was determined by measuring colony diameters in two perpendicular directions after 6 days of incubation in the dark at $20 \pm 1{ }^{\circ} \mathrm{C}$. Measurements were averaged, the diameter of the mycelial plug was subtracted, and relative growth reduction for each rate of fungicide was calculated as follows: $100-$ (growth with fungicide/growth in control plate) $\times 100$. The concentration resulting in $50 \%$ reduction of mycelial growth $\left(\mathrm{EC}_{50}\right)$ relative to the control was estimated by plotting the percent inhibition against the log-scale of fungicide concentration. Two independent trials were conducted to determine the $\mathrm{EC}_{50}$ values for each sensitivity test.

Temperature-dependent growth. The effect of temperature on in vitro growth was conducted on $P$. erythroseptica isolates 266-2, 364-5, 05NE1-3, E7, 06CO12, PE-89, 217-1, 05MN7-2, 06NE2-1, and 06CO1-1; P. nicotianae isolates 05NE1-2, 05NE1-5, 06FL1-7, 06FL1-9, 06TX1-3, 06TX1-6, 07TX1-1, 07TX2-2, 07MO1-1, 07MO1-2, and 07MO1-3; and P. cactorum isolates $05 \mathrm{MN} 55-1$ and $05 \mathrm{MN} 55-2$ (Table 1). Isolates were grown in the dark on CV8 agar medium at $20^{\circ} \mathrm{C}$. A cork borer was used to excise 5-mm-diameter disks containing mycelium and agar from the margin of actively growing colonies of 72-h cultures. Each disk was positioned in the center of a 9-cm culture dish containing CV8 agar medium, with the mycelium in contact with the medium. Culture dishes were incubated in the dark at 5, 15, 25, and $35^{\circ} \mathrm{C}$. Three culture dishes (replications) were prepared for each isolate at each temperature. Treatments (isolates grown at a specific temperature) were arranged in a completely random design in each incubator. Isolate growth was assessed daily by measuring colony diameters in two per- pendicular directions. Measurements were averaged and the diameter of the original mycelial plug was subtracted. Growth evaluations continued until the fastestgrowing isolate reached the margin of the culture dish. The experiment was performed twice.

Pathogenicity evaluations. Inoculum preparation. All test isolates were grown on culture plates containing CV8 juice agar in an environmentally controlled incubator at $20 \pm 1{ }^{\circ} \mathrm{C}$ in the dark. After 3 days, 5-mm-diameter disks containing mycelium and agar were removed from the margin of the colonies and placed in culture plates (three disks per plate) containing autoclaved clarified V8 broth $(100 \mathrm{ml}$ of clarified V8 juice and $900 \mathrm{ml}$ of deionized $\mathrm{H}_{2} \mathrm{O}$ ). After incubation for 3 days at $20 \pm 1^{\circ} \mathrm{C}$ in the dark, the clarified V8 juice broth subsequently was removed from the plates, and the mycelial mats were rinsed twice with $10 \mathrm{ml}$ of sterile deionized $\mathrm{H}_{2} \mathrm{O}$ and resuspended in $10 \mathrm{ml}$ of autoclaved, filtered soil extract from a potato field (10\% soil). Sporangial formation occurred after 36 to $48 \mathrm{~h}$ of incubation under constant illumination (eight Sylvania F20T12/ CW lamps) in an environmentally controlled incubator $\left(20 \pm 1^{\circ} \mathrm{C}\right)$. P. nicotianae isolates spontaneously released abundant zoospores within 24 to $36 \mathrm{~h}$ under these conditions without further treatment. For other species, zoospore release was stimulated by chilling cultures at $10 \pm 1^{\circ} \mathrm{C}$ for 1 $\mathrm{h}$ followed by a warming period at ambient temperature $\left(20\right.$ to $\left.25^{\circ} \mathrm{C}\right)$. Inoculum concentration was adjusted to $2 \times 10^{4}$ zoospores/ml using a hemacytometer. Zoospore suspensions were held in the dark at 8 to $10^{\circ} \mathrm{C}$ until inoculations were carried out, generally within 10 to $60 \mathrm{~min}$.

Preliminary tuber inoculations. The ability of $P$. nicotianae isolates from Florida (06FL1-7), Nebraska (05NE1-1), and Texas (06TX1-3) to infect tubers of four potato cultivars was assessed in laboratory challenge inoculation studies. Aggressiveness of these isolates was compared with a previously identified isolate of $P$. nicotianae $(\mathrm{N} 3)$ collected in Delaware and two isolates of $P$. erythroseptica (266-2 and 364-5) used in earlier pink rot studies $(29,30,32)$. Certified seed of potato cultivars (Atlantic, Red Norland, Russet Norkotah, and Snowden) displaying varying levels of susceptibility to P. erythroseptica-induced pink rot (23) were planted in irrigated research plots in central Minnesota. Each cultivar was grown in a block of four rows by $75 \mathrm{~m}$ and managed using agronomic practices typical of those recommended for potato production in that area. Plants were killed by mechanical flailing 2 to 3 weeks prior to maturity to insure the availability of a sufficient quantity of tubers of the desired size and adequate skin set. After harvest, tubers were held for 2 weeks at $15^{\circ} \mathrm{C}$ and $90 \%$ relative humidity to facilitate wound healing, then 
stored at $10^{\circ} \mathrm{C}$ until inoculation studies were conducted.

Disease-free tubers (140 to $190 \mathrm{~g}$ ) with apical eyes free of soil and having an intact periderm were hand selected for inoculation trials. Tubers were acclimated for 1 to 2 days at ambient temperature $\left(20\right.$ to $25^{\circ} \mathrm{C}$ ) and placed in plastic moist chamber boxes ( 33 by 24 by $12 \mathrm{~cm}$ ) lined at the bottom with moistened paper towels and inoculated with $10 \mu \mathrm{l}$ of the zoospore suspension (approximately 200 zoospores) on each of three apical eyes. Inoculated tubers were covered with four layers of paper towels moistened to saturation with deionized water. Chamber boxes were covered to establish high humidity to promote infection and placed in the dark at an ambient temperature of 20 to $22^{\circ} \mathrm{C}$ for 10 days. Inoculations were carried out as two separate trials, each consisting of four replications of 10 tubers per cultivar.

Cultivar susceptibility of tubers and foliage. Based on the results of preliminary pathogenicity experiments conducted on tubers, further studies were performed to determine the pathogenicity and aggressiveness of $P$. nicotianae and other Phytophthora spp. on foliage and in wounded and nonwounded tubers. Aggressiveness of isolates of $P$. nicotianae from Nebraska (05NE1-1 and 05NE1-2) and Texas (06TX1-3 and 06TX1-6) was compared with $P$. cactorum isolates (05MN55-1, $05 \mathrm{MN} 55-2$, and 05MN55-3) collected in Minnesota and known reference isolates of P. nicotianae (N3 and N5), P. erythroseptica (266-2 and 364-5), P. capsici (C19), and $P$. infestans (02-007-1 and 02-007-2) via foliar and tuber inoculations. Tubers selected from certified seed of potato cvs. Atlantic, Red Norland, Russet Burbank, Russet Norkotah, and Snowden were utilized in tuber inoculation experiments as well as to produce plant material for foliar inoculations. Tuber eyes (nonwounded) as well as tubers that had been wounded artificially by removing the periderm ( 1 by 1 $\mathrm{cm})$ with a no. 96 general-purpose, com- mercially available abrasive pad were inoculated with zoospore suspensions as previously described (30). Inoculations were carried out as two separate trials consisting of five replications, with one tuber per replication per cultivar.

Source plants for foliar inoculations were grown in the greenhouse from the same certified seed source as was used in the tuber inoculations. Seed tubers were planted in square, $13.5-\mathrm{cm}$ plastic pots containing Sunshine Mix Number 1 (SunGro Horticulture Canada Ltd., Seba Beach, $\mathrm{AB}$, Canada). Each pot received a single $9.86 \mathrm{~cm}^{3}$ application of Multicote 4 (1414-16+minors) control release fertilizer (Haifa NutriTech Inc., Altamnote Springs, FL) at planting. Plants were grown under $16 \mathrm{~h}$ of natural sunlight per day and ambient temperatures of 24 to $29^{\circ} \mathrm{C}$. Three leaves, having at least five fully expanded leaflets, were collected from each of the five cultivars prior to flowering and placed into plastic boxes containing moistened paper towels. A $20-\mu$ l drop of the zoospore suspension was deposited near the center of the long axis of each leaflet, in an area midway between the midvein and the margin of the leaflet. Five leaflets of each of three leaves were inoculated per isolate. Plastic boxes were sealed with Press'n Seal (The Glad Products Co., Oakland, CA) and leaves were incubated at ambient temperature $\left(20\right.$ to $25^{\circ} \mathrm{C}$ ) under constant fluorescent illumination for 7 days. Leaves were inverted with the abaxial side down to ensure the proper microclimate for infection $24 \mathrm{~h}$ after inoculation. Inoculations were carried out as two separate trials.

Disease assessment. Disease development in infected tubers was quantified using techniques similar to those described in earlier studies involving pink rot and leak $(23,29,30)$. Tubers inoculated in the apical eyes were removed from the moist chambers and infection was determined by cutting each tuber in half through the axis from the sites of inoculation on the apical bud end to the basal stem end. Tubers inoculated following wounding were bi-

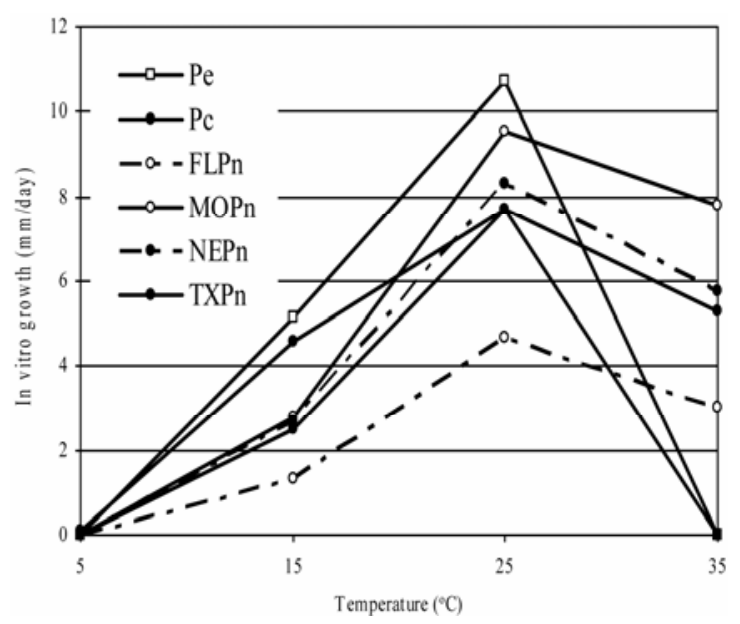

Fig. 3. Effect of temperature upon in vitro growth of Phytophthora erythroseptica (isolates 266-2, 3645, 05NE1-3, E7, 06CO1-2, PE-89, 217-1, 05MN7-2, 06NE2-1, and 06CO1-1), P. cactorum (isolates (05MN55-1 and 05MN55-2), and P. nicotianae isolates from Florida (06FL1-7 and 06FL1-9), Missouri (07MO1-1, 07MO1-2, and 07MO1-3), Nebraska (05NE1-2 and 06NE1-5), and Texas (06TX1-3, 06TX1-6, 07TX1-1, and 07TX2-2).

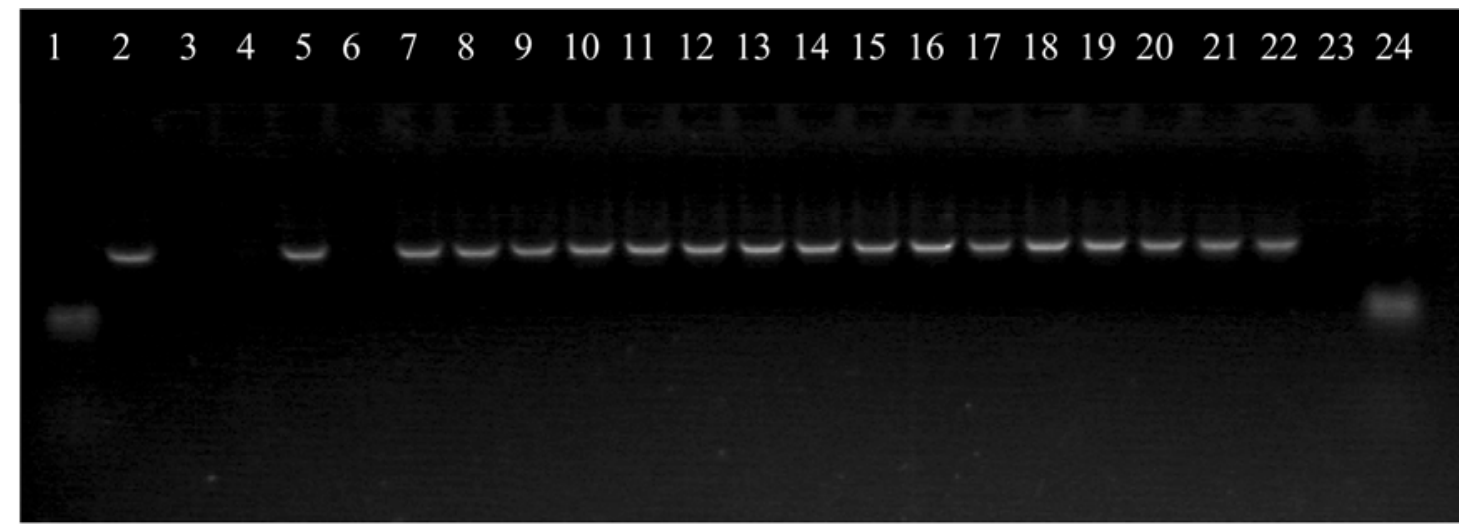

Fig. 2. Polymerase chain reaction amplification using Phytophthora nicotianae species-specific primers. P. nicotianae positive control (lane 2), $P$. infestans negative control (lane 3), P. erythroseptica negative control (lane 4), PnN3 (lane 5), 05MN55-1 (lane 6), 05NE1-2 (lane 7), 06GA1-7 (lane 8), 06GA1-9 (lane 9), 06NE1-1 (lane 10), 06TX1-1 (lane 11), 07TX1-1 (lane 12), 07TX1-2 (lane 13), 07TX1-3 (lane 14), 07TX1-4 (lane 15), 07TX1-5 (lane 16), 07TX1-6 (lane 17), 07TX1-7 (lane 18), 07TX1-8 (lane 19), 07TX1-9 (lane 20), 07TX2-1 (lane 21), and 07TX2-2 (lane 22). Lanes 1 and 24 contain a 1-kb ladder, and lane 23 contains a no-template control. 
sected through the point of inoculation, perpendicular to the longitudinal axis. Split tubers were covered with moist paper towels and incubated at ambient temperatures of 20 to $24^{\circ} \mathrm{C}$ for approximately $30 \mathrm{~min}$ to enhance the development of the discoloration diagnostic of pink rot infection. Infected tubers were counted and disease incidence was calculated as follows: (number of diseased tubers/number of inoculated tubers $) \times 100$. To determine disease severity, the maximum depth (D) of rotted tissue was measured from the point of inoculation and penetration rate (P) was calculated as $\mathrm{P}=\mathrm{D} / \mathrm{T}$, where $\mathrm{T}$ is time in days after inoculation.

Disease development in infected leaves was quantified by scoring leaflets for lesion expansion from 2 to 7 days after inoculation and incidence of sporulation and infection at 7 days after inoculation. Severity of infection was rated on a 0 -to-5 scale according to the size of the lesion, where 0 $=$ no visible lesion, $1=$ necrotic flecking $<1 \mathrm{~cm}$ in diameter, $2=$ necrotic spots between 1 and $2 \mathrm{~cm}$ in diameter, $3=2$ to 3 $\mathrm{cm}$ in diameter, $4=3$ to $4 \mathrm{~cm}$ in diameter, and $5=>4 \mathrm{~cm}$ in diameter. The develop- ment of small, necrotic, hypersensitive spots was not considered true pathogen infection and was not used to calculate infection incidence or lesion expansion. The ability of the pathogen to sporulate was rated as: no mycelial growth or sporulation observed, mycelial growth with little or no sporulation, and dense sporulation. Incidence was determined by counting the number of visible lesions greater than $1 \mathrm{~cm}$ in diameter and calculating the frequency of infection out of 15 total leaflets inoculated per isolate-cultivar combination. Those lesions remaining $<1 \mathrm{~cm}$ and scored as 1 after 7 days were considered to be the result of a hypersensitive response and were not considered to be the result of active pathogen growth. The area under the lesion expansion curve (AULEC) was calculated according to a modified formula based upon the formula of Shaner and Finney (26) for area under the disease progress curve (AUDPC):

$$
\text { AULEC }=\sum_{i=1}^{n}\left[\left(W_{i+n 1}+W_{i}\right) / 2\right]\left(t_{i+1}-t_{i}\right)
$$

where $W_{i}=$ lesion diameter rating at the $i$ th observation, $t_{i}=$ time in days at the $i$ th observation, and $n=$ total number of observations.

Data analysis. Levene's test for homogeneity of variance was conducted on all tuber and foliar inoculation trials as well as temperature-dependent growth experiments to ensure that data could be combined for further analysis (17). Data for individual $P$. erythroseptica, $P$. cactorum, and $P$. infestans isolates were pooled by species. $P$. nicotianae isolates were subdivided by location in foliar and tuber cultivar susceptibility experiments as well as temperature-dependent growth experiments. A one-way analyses of variance (ANOVA) was performed using PROC GLM (SAS, version 9.0; SAS Institute Inc., Cary, NC) among isolate groups for in vitro growth at each temperature for temperature-dependent growth data and for disease incidence and severity for pathogenicity and cultivar-susceptibility experiments. To compare susceptibility across cultivars to $P$. nicotianae, disease incidence data from tuber pathogenicity and cultivar-susceptibility experiments were combined using Levene's method for all isolates of $P$. nicotianae and a one-way

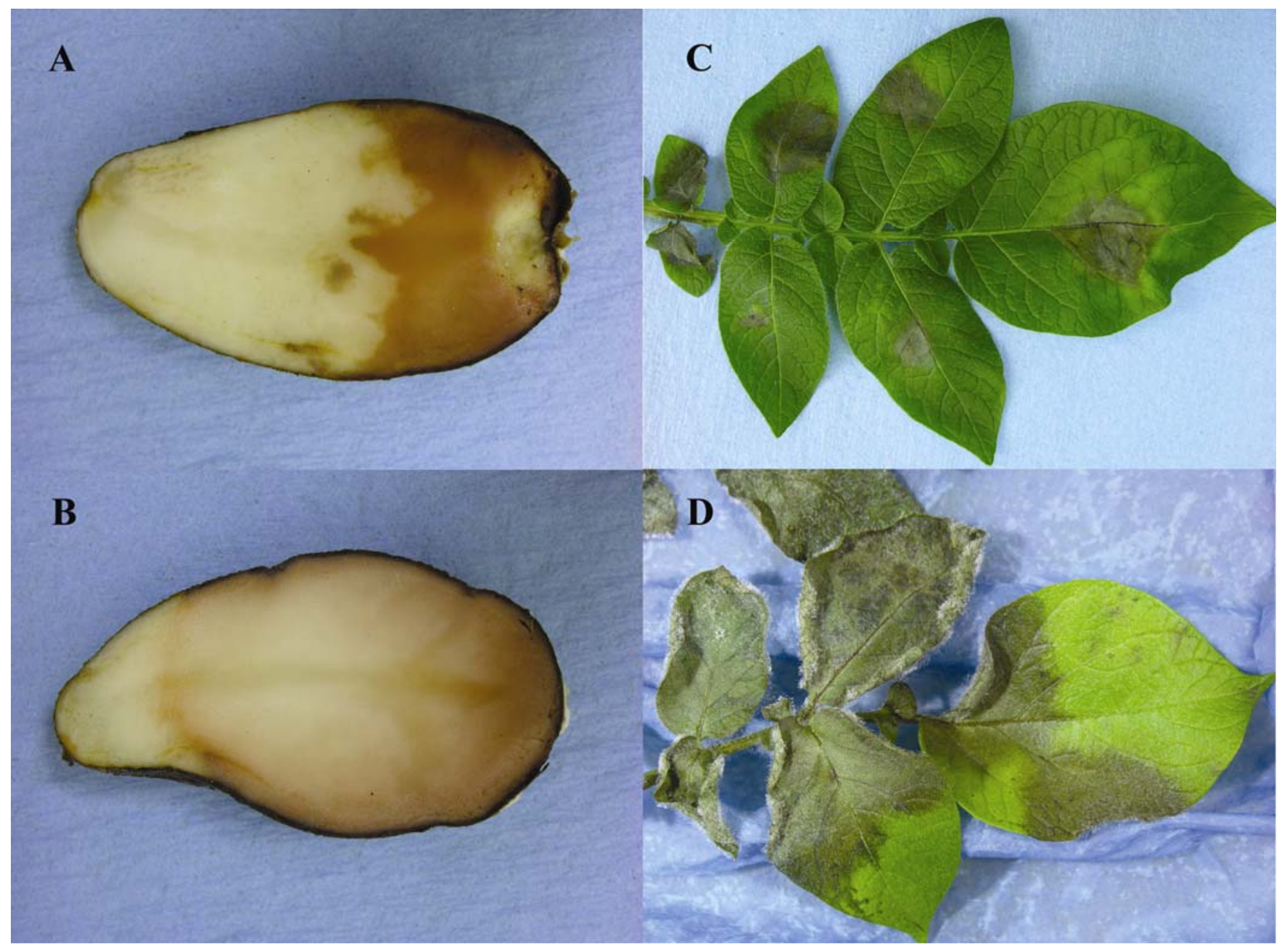

Fig. 4. Symptoms of Phytophthora nicotianae infections of potato tuber tissue (cv. Red Norland) inoculated with A, $P$. nicotianae isolate 06TX1-6 and B, $P$. erythroseptica isolate 364-5 and foliar tissue (cv. Atlantic) inoculated with $\mathbf{C}, P$. nicotianae and $\mathbf{D}, P$. infestans. Note sporulation on leaf infected with $P$. infestans but absent on leaf infected with $P$. nicotianae. 
ANOVA was performed. Differences in mean fungal lesion expansion and in vitro growth, disease incidence, and severity of infection of inoculated tubers, as well as mean disease incidence of foliar infection and AULEC, were determined using Fisher's protected least significant difference (LSD) test ( $\alpha=0.05$ ). Pearson's correlation coefficient was utilized to compare disease incidence of tuber infection by $P$. nicotianae and $P$. erythroseptica among cultivars inoculated in the preliminary, nonwounded, and wounded pathogenicity

\section{RESULTS}

Isolate identification and characterization. Morphological characterization. Isolates recovered from infected tubers collected in Nebraska in 2005 and leaves in 2006, tubers from Florida in 2006, leaves from Texas in 2006 and 2007, and tubers from Missouri in 2007 all were identified as $P$. nicotianae. One isolate (05MN55-1) recovered from an infected leaf collected in Minnesota in 2005 was identified as $P$. cactorum (Table 1). Two other isolates (05MN55-2 and 05MN55-3) were designated as $P$. cactorum based on morphological characteristics identical to isolate 05MN55-1. All isolates had hyphae experiments.

typical of Phytophthora spp., with slight to prominent hyphal swellings in CA. Colony type varied slightly among isolates, with all but one isolate having a rosette to arachnoid colony type typical of $P$. nicotianae. Isolate 05MN55-1 had a slightly petaloid to very diffuse colony type described for P. cactorum. All 32 P. nicotianae isolates produced typical sporangia and chlamydospores in CA, but the intensity of sporulation varied with isolate. Sporangia were variable in size and shape; most sporangia were ellipsoid, ovoid, obpyriform, or spherical, and all had prominent papilla. Isolates of $P$. cactorum produced typical sporangia for the species, but chlamydospores were not observed in CA. Oospores were abundant in the isolates of $P$. cactorum, but no oospores were produced in the isolates of $P$. nicotianae.

Species-specific amplification. DNA samples were assayed using PCR primers specific to $P$. nicotianae. A known isolate of $P$. nicotianae was included as a positive control, and $P$. infestans and $P$. erythroseptica, both important potato pathogens, were included as negative controls. Negative controls from the collections of Neil Gudmestad (P. erythroseptica) and Jean Ristaino ( $P$. infestans) were identified previously based upon morphological charac-
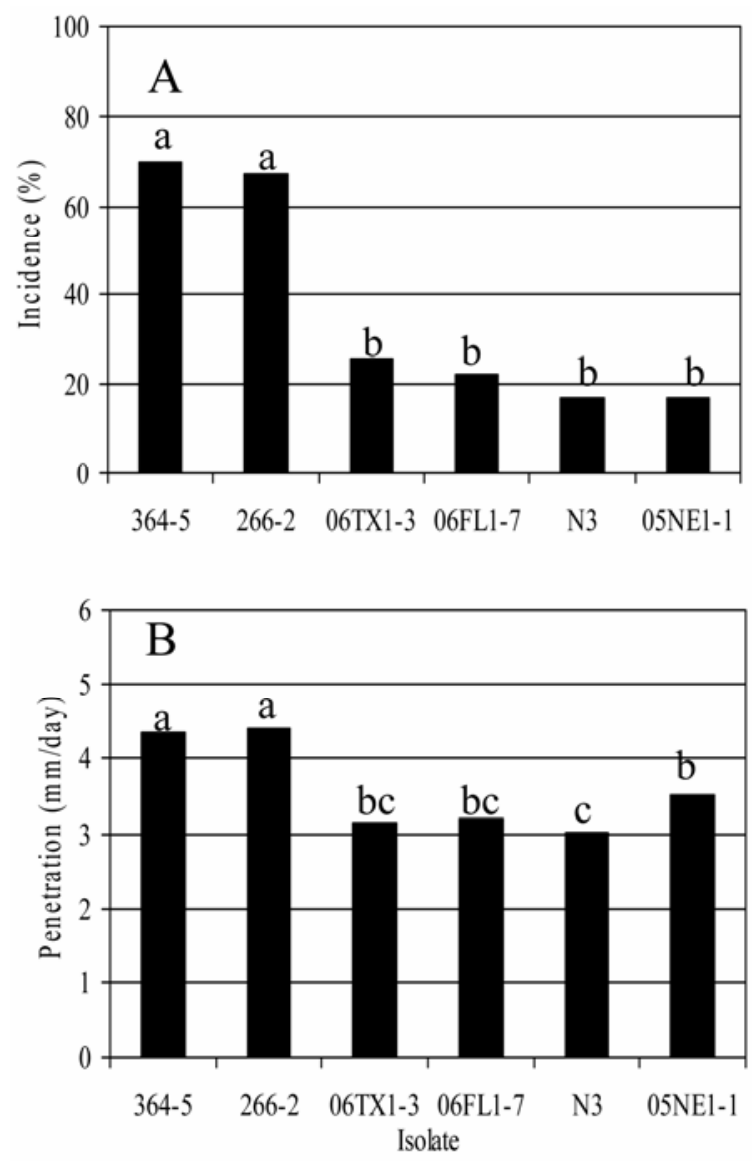

Fig. 5. A, Incidence and B, penetration of tubers of four potato cultivars following inoculation of tuber eyes by zoospore suspensions of Phytophthora erythroseptica isolates (364-5 and 266-2) and isolates of P. nicotianae obtained from Texas (06TX1-3), Florida (06FL1-7), Delaware (N3), and Nebraska (05NE1-1). Columns with the same letter are not statistically different based on Fisher's protected least significant difference $(P=0.05)$. teristics and pathogenicity or DNA characterization. The species-specific primers amplified the positive control but neither of the negative controls. All of the isolates identified as $P$. nicotianae based on morphological features were amplified using the species-specific primers (Fig. 2). The isolate of $P$. cactorum also was not amplified.

ITS sequencing was completed to confirm identification of the $P$. nicotianae isolates and one isolate of P. cactorum. Sequences were blasted against GenBank accessions through National Center for Biotechnology Information blastn. Isolate 05MN55-1 was 99\% identical to $P$. cactorum, and all other isolates were identified as $P$. nicotianae based on similarity to reported $P$. nicotianae isolates.

Mating type. Mating type was determined successfully for all isolates (Table 1). All isolates of $P$. nicotianae were the A1 mating type except for three of the Nebraska isolates (05NE1-1, 05NE1-2, and 06NE1-1), which were A2, and one of the Texas isolates (06TX1-1), which produced oospores with both testers and was scored as an A1/A2. Missouri isolate 07MO1-7 did not produce oospores with either tester and subsequently was scored AO.

Mefenoxam sensitivity. Isolates of $P$. nicotianae from Florida, Missouri, Nebraska, and Texas all were sensitive to mefenoxam, with $\mathrm{EC}_{50}$ values ranging from 0.07 to $0.42 \mu \mathrm{g} / \mathrm{ml}$ (Table 1). P. cactorum isolates $05 \mathrm{MN} 55-1,05 \mathrm{MN} 55-2$, and 05MN55-3 also were sensitive, as were reference $P$. nicotianae isolates $\mathrm{N} 3(0.32$ $\mu \mathrm{g} / \mathrm{ml})$ and $\mathrm{N} 5(0.29 \mu \mathrm{g} / \mathrm{ml})$ and $P$. erythroseptica isolates $266-2(0.02 \mu \mathrm{g} / \mathrm{ml}), 364$ $5(0.04 \mu \mathrm{g} / \mathrm{ml}), 05 \mathrm{NE} 1-3(0.04 \mu \mathrm{g} / \mathrm{ml}), \mathrm{E} 7$ $(0.07 \mu \mathrm{g} / \mathrm{ml})$, and 06CO1-2 $(0.08 \mu \mathrm{g} / \mathrm{ml})$. Other $P$. erythroseptica isolates included for comparison in the temperaturedependent growth study were resistant to mefenoxam $(>100 \mu \mathrm{g} / \mathrm{ml})$.

Temperature-dependent growth. Optimum growth of $P$. nicotianae, $P$. cactorum, and $P$. erythroseptica isolates occurred at $25^{\circ} \mathrm{C}$. Growth of $P$. erythroseptica was significantly greater than either $P$. nicotianae or $P$. cactorum isolates at that temperature (Fig. 3). Growth of $P$. erythroseptica and $P$. cactorum isolates at $15^{\circ} \mathrm{C}$ was significantly greater and nearly double that recorded for isolates of $P$. nicotianae. All $P$. nicotianae isolates sustained active growth at $35^{\circ} \mathrm{C}$, whereas isolates of $P$. erythroseptica and $P$. cactorum did not. Significant differences in growth among $P$. nicotianae isolates obtained from different locations were observed at 15, 25, and $35^{\circ} \mathrm{C}$ and among $P$. nicotianae isolates. Isolates from Missouri grew most rapidly, whereas isolates from Florida consistently had the least growth at each temperature. Growth of $P$. nicotianae isolates from Missouri at $35^{\circ} \mathrm{C}$ was $82 \%$ of that observed at $25^{\circ} \mathrm{C}$. Likewise, growth of $P$. nicotianae 
isolates from Nebraska, Texas, and Florida ranged from 65 to $70 \%$ of the maximum observed at $25^{\circ} \mathrm{C}$.

Pathogenicity evaluations. Preliminary tuber inoculations. Tuber symptoms caused by $P$. nicotianae were typical of pink rot symptoms resulting from $P$. erythroseptica infections; however, the pink discoloration was not as intense with $P$. nicotianae and the infected tissue became tan to pale brown after extended exposure to air (Fig. 4A and B). A significant difference in disease incidence and disease severity among isolates was observed. Isolates of $P$. nicotianae from Texas (06TX13), Florida (06FL1-7), Nebraska (05NE11 ), and reference isolate N3 from Delaware were pathogenic, infecting tubers following eye inoculation of nonwounded tubers with zoospore suspensions (Fig. 5A). Across cultivars, disease incidence was highest with $P$. erythroseptica isolates 364$5(70 \%)$ and 266-2 (67\%). P. nicotianae isolates were significantly less aggressive, with disease incidences values between 17 and $26 \%$. Disease severity followed a similar pattern. Tissue penetration by $P$. erythroseptica isolates $364-5$ and 266-2 was significantly greater than colonization by any of the P. nicotianae isolates (Fig. 5B).
Across $P$. nicotianae isolates, cv. Red Norland was the most susceptible cultivar, but only significantly so when compared with cv. Snowden. Colonization of tuber tissue was significantly slower in cv. Atlantic than in cvs. Red Norland and Snowden (data not shown).

Cultivar susceptibility of tubers and foliage. A significant difference was observed in disease incidence and disease severity between wounded and nonwounded tubers; therefore, these data were analyzed separately. Following tuber eye inoculation of nonwounded tubers, significant differences in disease incidence among isolate groups were observed across the five cultivars used in this study (Fig. 6A). Control isolates of P. erythroseptica (364-5, 266-2) P. nicotianae (N3 and N5), and $P$. infestans (02-007-1 and 02-007-2) infected nonwounded potato tubers via eye inoculation with zoospore suspensions, as did $P$. nicotianae isolates from Nebraska (05NE1-1 and 05NE1-2) and Texas (06TX1-3 and 06TX1-6) (Fig. 6A). The highest infection frequencies were obtained with isolates of $P$. erythroseptica and disease incidence was significantly lower following inoculation with $P$. nicotianae and $P$. infestans isolates.
Disease incidence did not differ among $P$. nicotianae isolates from Delaware, $\mathrm{Ne}$ braska, and Texas, and was similar to the infection frequency observed with isolates of $P$. infestans. In contrast, isolates of $P$. cactorum (05MN55-1, 05MN55-2, and $05 \mathrm{MN} 55-3$ ) obtained from naturally occurring potato leaf infections in Minnesota, and the P. capsici control isolate $\mathrm{C} 19$ from pepper, did not infect nonwounded tubers. Significant differences in colonization of nonwounded tuber tissue also were noted among Phytophthora spp. (Fig. 5B). The highest level of penetration was observed with isolates of $P$. erythroseptica (5.2 $\mathrm{mm}$ /day), which was significantly greater than penetration by $P$. nicotianae isolates from Texas. Penetration by $P$. nicotianae isolates from Delaware and Nebraska was similar to isolates of $P$. erythroseptica. Penetration rates by $P$. nicotianae isolates from Delaware, Nebraska, and Texas ranged from 3.7 to $4.5 \mathrm{~mm} /$ day. The penetration rate of $P$. infestans isolates $(0.7$ $\mathrm{mm} /$ day) was significantly lower than rates observed for isolates of $P$. erythroseptica and $P$. nicotianae.

Wounding also affected infection efficiency. Disease incidence increased significantly following abrasive removal of
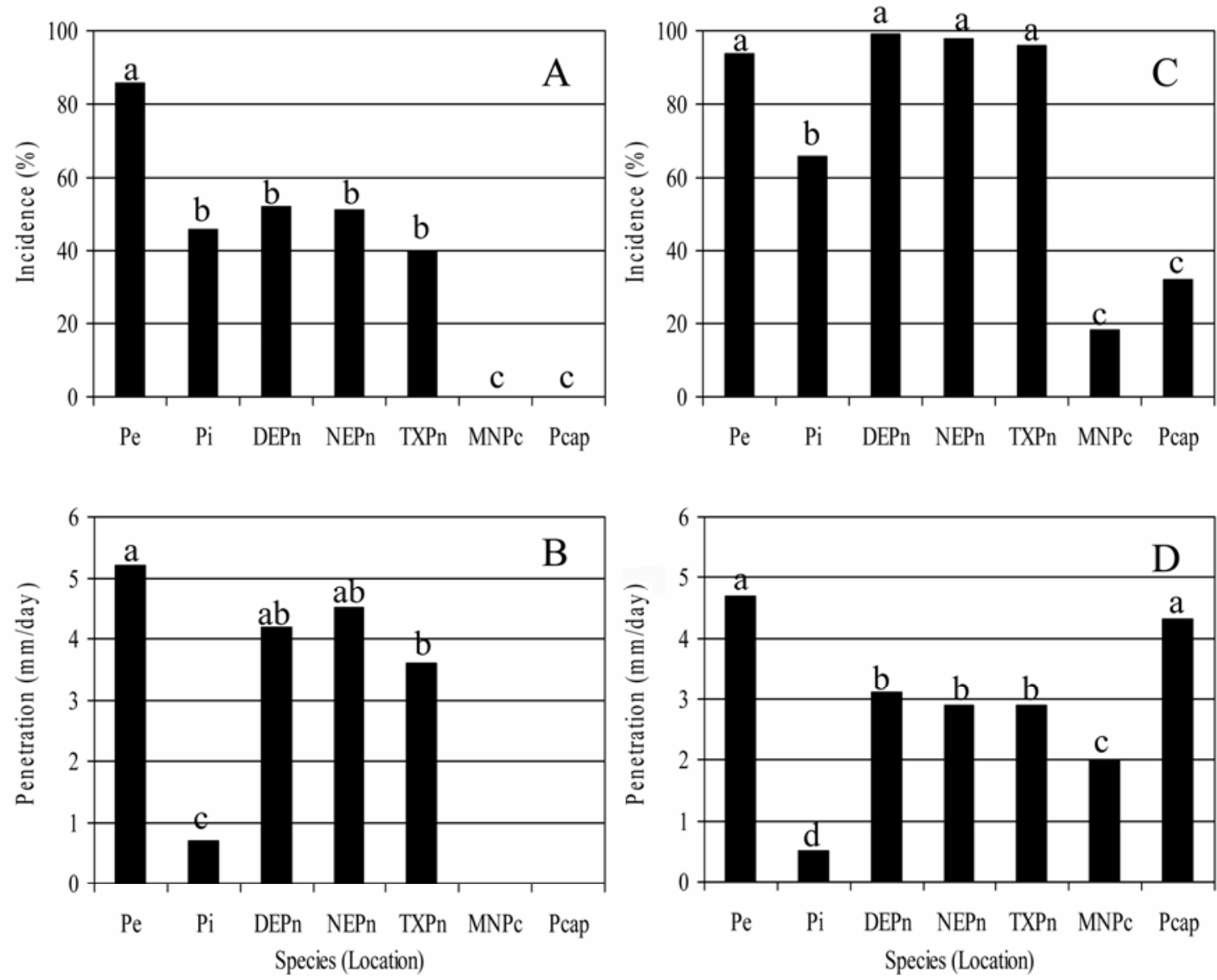

Fig. 6. A and $\mathbf{C}$, Incidence and $\mathbf{B}$ and $\mathbf{D}$, penetration of potato tubers following inoculation of $\mathbf{A}$ and $\mathbf{B}$, tuber eyes and $\mathbf{C}$ and $\mathbf{D}$, wounds with zoospore suspensions of Phytophthora erythroseptica isolates (364-5 and 266-2; Pe), P. infestans (02-007-1 and 02007-2; Pi), P. capsici (C19; Pcap), and isolates of P. nicotianae obtained from Texas (06TX1-3 and 06TX1-6; TXPn), Delaware (N3 and N5; DEPn), Nebraska (05NE1-1 and 05NE1-2; NEPn) and Minnesota (05MN55-1, 05MN55-2, and 05MN55-3; MNPc). Columns with the same letter are not statistically different based on Fisher's protected least significant difference $(P=0.05)$. 
the periderm compared with nonwounded eye inoculations. Additionally, in contrast to the results obtained in nonwounded tubers, all Phytophthora spp. were able to infect wounded tubers, and significant differences in aggressiveness were observed among groups (Fig. 6A and C). This was most notable with $P$. capsici and $P$. cactorum, which were not able to infect nonwounded tuber tissue, and P. nicotianae, where wounding nearly doubled infection frequencies. Infection frequencies obtained with $P$. erythroseptica and $P$. nicotianae were similar, ranging from 94 to $99 \%$ following wounding. Infection frequencies observed for $P$. infestans (66\%), P. capsici (32\%), and P. cactorum $(18 \%)$ were significantly lower than observed with the other species. Although infection frequency was low, tissue penetration by $P$. capsici was similar to the rate of penetration observed with P. erythroseptica and significantly greater than that of $P$. infestans, $P$. nicotianae, and $P$. cactorum (Fig. 6D). P. erythroseptica and P. capsici had the highest rates of tissue colonization at 4.7 and $4.3 \mathrm{~mm} /$ day, respectively. Penetration rates of $P$. nicotianae from Delaware, Nebraska, and Texas differed significantly from those isolates, ranging from 2.9 to $3.1 \mathrm{~mm} /$ day. P. infestans and P. cac- torum had significantly lower rates of tissue colonization at 0.5 and $2.0 \mathrm{~mm} /$ day, respectively.

Across $P$. nicotianae isolates, nonwounded tubers of cv. Red Norland were most susceptible, supporting the preliminary tuber inoculation experiments, and were significantly more susceptible than cvs. Russet Burbank and Atlantic (Fig. 7A). Tuber tissue colonization was greatest in cvs. Atlantic, Red Norland, and Russet Norkotah, ranging from 4.7 to $5.5 \mathrm{~mm} /$ day, and was significantly lower in cvs. Snowden and Russet Burbank, penetrating 3.3 and $3.2 \mathrm{~mm} /$ day, respectively (Fig. 7B). Percent disease incidence ranged from 96 to $100 \%$ among cultivars wounded and inoculated with $P$. nicotianae isolates; therefore, there was no difference observed in the level of susceptibility to this pathogen when wounding has occurred (Fig. 7C). However, rates of penetration of wounded tissue did differ among the cultivars (Fig. 7D). As with nonwounded tissue, cvs. Atlantic, Red Norland, and Russet Norkotah suffered the highest rate of pathogen penetration. A significant correlation $(r=0.72, P=0.0038)$ existed for pink rot incidence caused by $P$. erythroseptica and $P$. nicotianae among cultivars used in all tuber inoculation experiments (Fig. 8).
As was observed with nonwounded tuber tissue, isolate groups of Phytophthora spp. differed significantly in foliar infection frequency (Fig. 9A). P. infestans isolates infected foliage with $100 \%$ efficiency and isolates of $P$. nicotianae from Delaware $(88 \%)$, Nebraska $(73 \%)$, and Texas $(50 \%)$ also infected foliage more frequently than isolates of $P$. erythroseptica (38\%). Control P. capsici isolate C19 and $P$. cactorum isolates from Minnesota were the least aggressive. Although P. capsici was able to infect nearly $10 \%$ of the time, isolates of $P$. cactorum produced only necrotic hypersensitive reactions on the foliage.

Lesion expansion in infected leaf tissue also differed significantly among isolate groups (Fig. 9B). AULEC was similar for $P$. infestans and $P$. nicotianae isolates (Fig. 9B). P. erythroseptica isolates and P. cactorum isolates from Minnesota did infect foliar tissue, but at a significantly slower rate. $P$. capsici was incapable of infecting potato foliage. Foliar symptoms caused by $P$. nicotianae isolates were nearly indistinguishable from that of $P$. infestans (Fig. 4C and D). However, $P$. infestans produced abundant sporulation under conditions of high relative humidity $(>90 \%)$ provided in this experiment, in contrast to the isolates
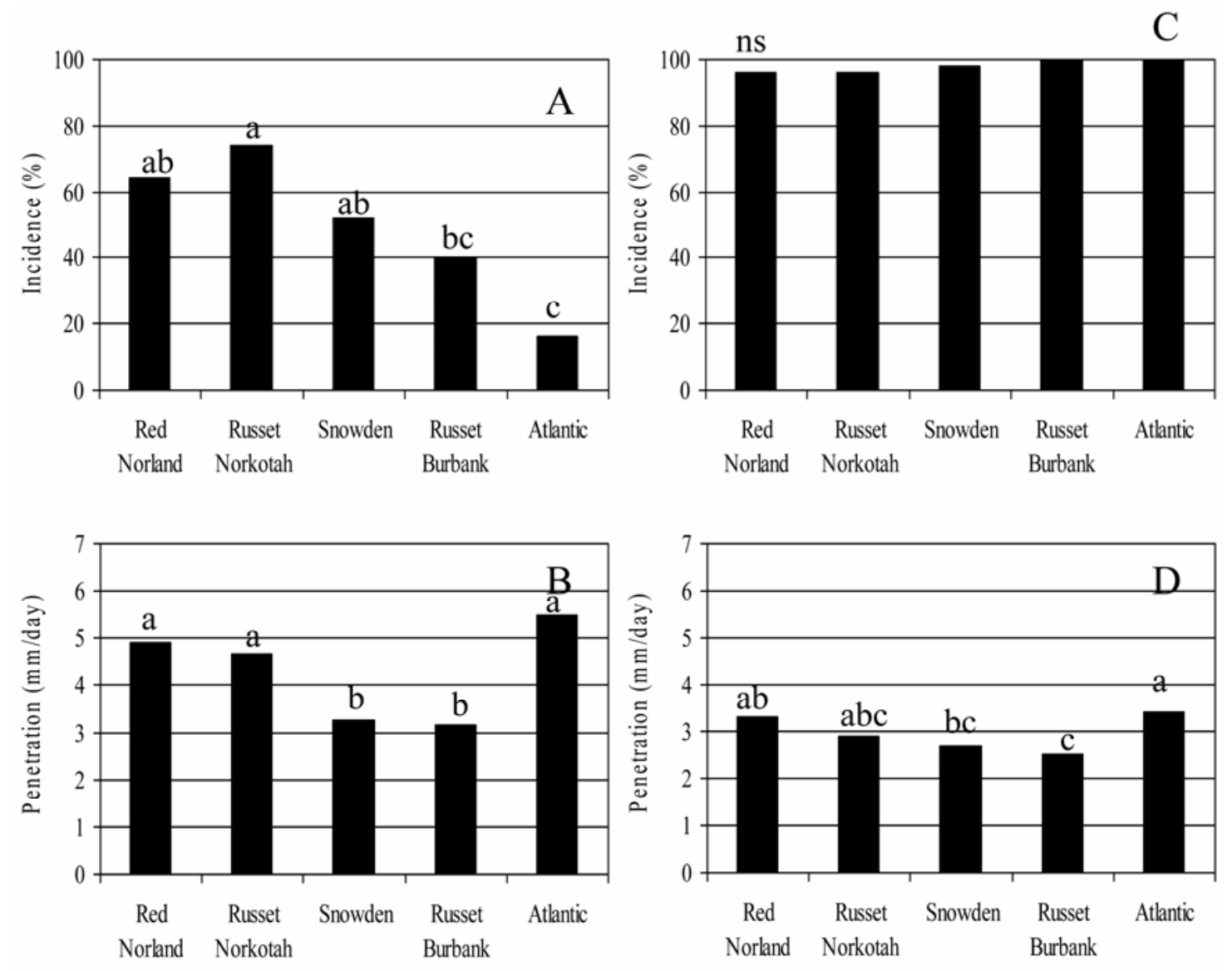

Cultivar

Cultivar

Fig. 7. $\mathbf{A}$ and $\mathbf{C}$, Incidence and $\mathbf{B}$ and $\mathbf{D}$, penetration of tubers of five potato cultivars following inoculation of $\mathbf{A}$ and $\mathbf{B}$, tuber eyes and $\mathbf{C}$ and $\mathbf{D}$, wounds by zoospore suspensions of Phytophthora nicotianae isolates N3, 06TX1-3, 05NE1-1, and 06FL1-7. Columns with the same letter are not statistically different based on Fisher's protected least significant difference $(P=0.05)$. 
of $P$. nicotianae evaluated, where mycelial growth and sporangiophores were observed but sporangia were not produced (data not shown). Additionally, no sporulation was observed for isolates of $P$. erythroseptica, $P$. capsici, or $P$. cactorum on inoculated foliage of any cultivar.

\section{DISCUSSION}

Late blight is a disease of potato that elicits an immediate and dramatic response by most potato producers. Because the disease can progress very rapidly and destroy potato foliage in a very short time under conducive weather conditions, potato producers generally are inclined to reduce risk by the application of preventative fungicides such as mancozeb or chlorothalonil. However, if late blight is found in a field, the grower response is likely to be more drastic and will include the applications of fungicide chemistries more efficacious and more expensive. In the presence of mefenoxam-resistant $P$. infestans, these fungicides include cymoxanil, cyazofamid, dimethomorph, famoxadone, fenamidone, propamocarb, or zoxamide. These fungicides individually represent an increase in cost of late blight control two to three times that of preventative fungicides such as mancozeb or chlorothalonil.

It is because of the importance of late blight as a potato disease that we became aware of foliar infections of $P$. nicotianae on potato. Under wet weather conditions in a number of Southern potato production states, $P$. nicotianae was able to infect potato foliage. However, the disease frequently is confined to low areas in fields and along irrigation tracks (Fig. 1C) where standing water persists because of soil compaction. These observations suggested that the foliar disease does not spread via the production of secondary inoculum originating from primary lesions. However, continued wet weather can cause additional primary infections to occur, giving the appearance of a secondary pathogen cycle. Controlled inoculations under conducive environmental conditions support our field observations because we failed to find evidence of sporangial production from foliar lesions as we did with $P$. infestans. Nonetheless, in southern Texas in early 2007 , which was characterized by unusually wet weather over a prolonged period, several $P$. nicotianae infection events occurred and a number of growers expressed concern about the severity the disease. Because the data collected at the time suggested that the $P$. nicotianae isolates were mefenoxam sensitive, we recommended that they use this fungicide chemistry, which they did successfully. $P$. nicotianae isolates recovered from the South Texas and Missouri epidemics were included in the studies reported here and subsequently found to be mefenoxam sensitive.
P. nicotianae is known to cause foliar and stem blights in numerous plant species (8), including potato (34), where foliar infections where observed via artificial inoculation. Person and Nielsen (20) described symptoms of foliar and stem infections occurring in North Carolina and also were able to produce leaf infections by inoculation under laboratory conditions. Our observations provide additional insights into P. nicotianae-induced blight of potato. Disease incidence did not differ significantly among the five cultivars used to evaluate foliar infection, suggesting that

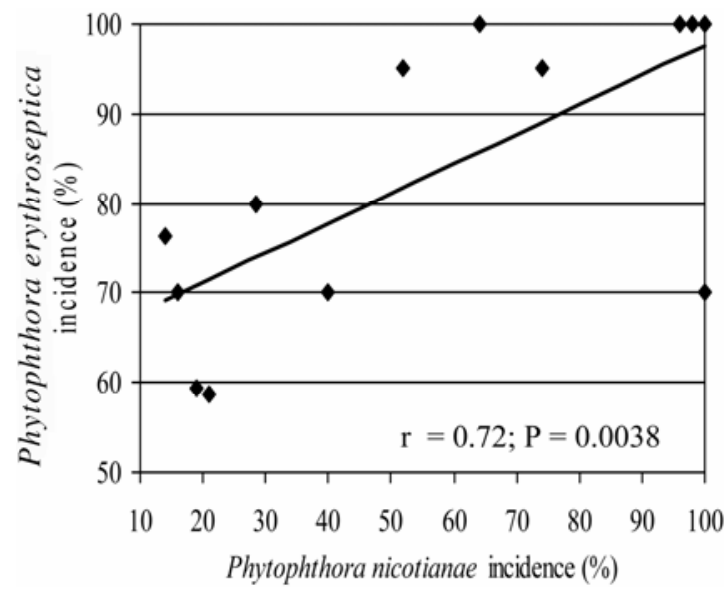

Fig. 8. Pearson's correlation coefficient comparing the percent disease incidence of tubers from cvs. Atlantic, Russet Norkotah, Red Norland, Russet Burbank, and Snowden inoculated with Phytophthora erythroseptica and $P$. nicotianae in the preliminary, nonwounded, and wound inoculation experiments.
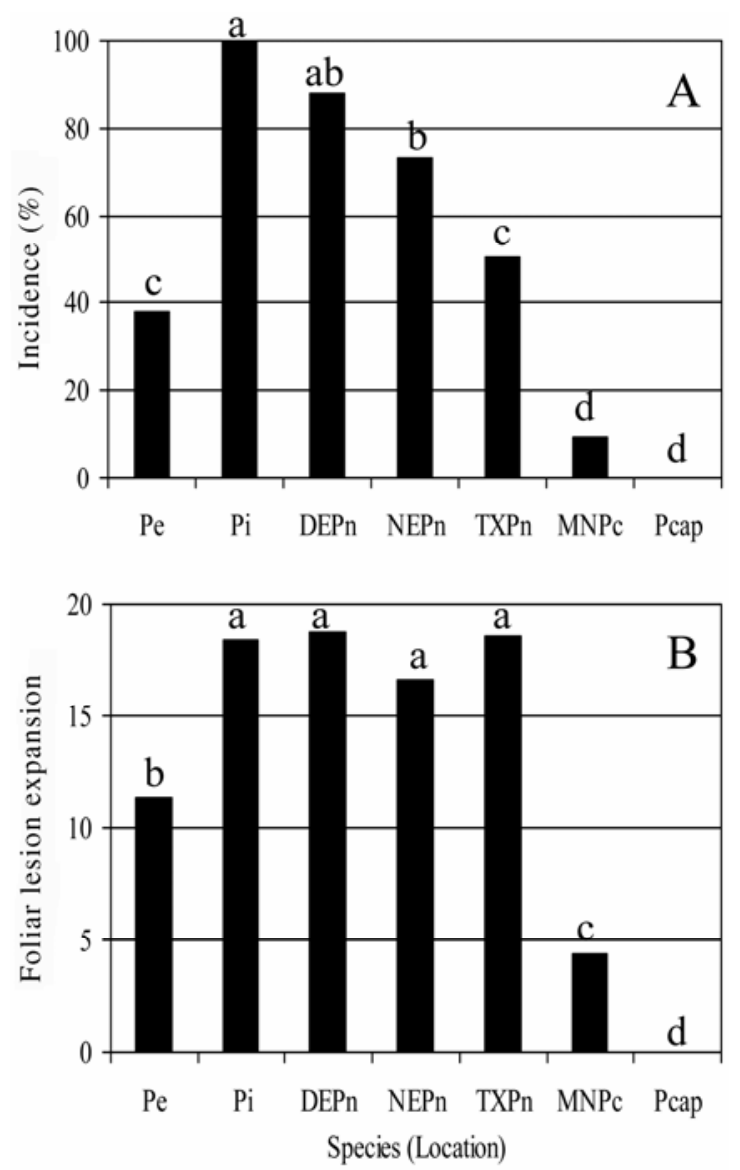

Fig. 9. A, Incidence of foliar infection and $\mathbf{B}$, foliar lesion expansion illustrated by area under the lesion expansion curve following inoculation of leaflets of five potato cultivars by zoospore suspensions of Phytophthora erythroseptica isolates (364-5 and 266-2; Pe), P. infestans (02-007-1 and 020072; Pi), P. capsici (C19; Pcap), and isolates of P. nicotianae obtained from Texas (06TX1-3 and 06TX16; TXPn), Delaware (N3 and N5; DEPn), Nebraska (05NE1-1 and 05NE1-2; NEPn), and Minnesota (05MN55-1, 05MN55-2, and 05MN55-3; MNPc). Columns with the same letter are not statistically different based on Fisher's protected least significant difference $(P=0.05)$. 
current genotypes may be equally susceptible to attack by $P$. nicotianae. Additionally, incidence and extent of lesion development with $P$. nicotianae isolates 05NE11 and 05NE1-2 did not differ from levels attained with $P$. infestans. Therefore, it appears that some $P$. nicotianae isolates are capable of causing foliar damage comparable in aggressiveness to $P$. infestans. Based upon our observations and those of earlier workers (20), the symptoms of foliar and stem infections caused by $P$. nicotianae are indistinguishable from potato late blight in the field. Lesion shape and size are typical of those caused by $P$. infestans, lesions generally are found on lower plant parts, and mycelium often can be seen within the infected lesion area. The primary difference is that sporangia are rarely, if ever, produced with blight caused by $P$. nicotianae and lesions devoid of sporangia may be found on infected plants for extended periods of time. This obviously impacts the epidemiology of $P$. nicotianae versus $P$. infestans, making the former less explosive as a foliar disease of potato. The lack of true sporulation of $P$. nicotianae also provides a means to distinguish infections of this pathogen from $P$. infestans and can be utilized in the field by crop consultants and field scouts working in the potato industry.

Although numerous Phytophthora spp. have been reported to infect tuber tissue resulting in pink-rot-like symptoms (8), $P$. erythroseptica is considered to be the primary cause of pink rot in most potatogrowing regions. Results obtained by our research group in an extensive sampling of tubers exhibiting typical pink rot symptoms are consistent with these observations (31). Only $P$. erythroseptica was isolated from infected tuber tissue during this study, which involved $>2,000$ tubers from various potato-growing areas in the United States spanning multiple years. Other Phytophthora spp. rarely are associated with the pink rot, particularly in North America. However, in 2005, we isolated P. nicotianae from tubers originating in Nebraska. Foliar samples also were received from Nebraska that year displaying late-blightlike symptoms; however, the pathogen was not recovered at that time. Isolates were recovered from foliage collected in $\mathrm{Ne}$ braska in 2006. That same year, P. nicotianae was isolated from tubers collected in Florida and leaves obtained from potato plants growing in a commercial field in Texas. In 2007, the pathogen was isolated again from leaves collected in Texas as well as tubers from Missouri. It is interesting to note that the only isolates of $P$. nicotianae of the A2 mating type have been recovered from Nebraska, where the A1 mating type also was recovered. Thus, it would appear at this time that Nebraska is the only state in which both mating types of this pathogen that affect potato exist. Although we presume that $P$. nicotianae is surviving as chlamydospores in the soil, it is intriguing that, if both mating types are present, oospores may be forming in some locations

Since the first report of $P$. nicotianae ( $P$. parasitica) infecting potato tubers in Oklahoma and Kentucky under field conditions (6), the pathogen has been reported to cause tuber pink rot in Texas (12) and has been isolated from symptomatic tubers in Delaware (18). The current study supplements this information by reporting the first occurrences of pink rot in Nebraska, Florida, and Missouri caused by $P$. nicotianae. From the studies reported here, it is apparent that $P$. nicotianae is not as aggressive as $P$. erythroseptica in causing pink rot; thus, it is likely that its occurrence and distribution in southern states most probably is due to a greater tolerance to higher temperatures as evidenced by our vitro growth experiments.

Lambert and Salas (15) asserted that $P$. nicotianae is likely to be more prevalent than $P$. erythroseptica under hot growing conditions, thus implying that $P$. nicotianae could be a major cause of pink rot under those conditions. This view is supported by the fact that most early observations of foliar and tuber infections were made in potato-growing areas generally having warm growing seasons, such as those in Delaware and New Jersey (18), Kentucky and Oklahoma (6), North Carolina (20), and Texas (12). Erwin and Ribeiro (8) reported maximum growth temperatures of 33 to $40^{\circ} \mathrm{C}$ for P. nicotianae isolates from a variety of host species, and Wijers (36) recorded maximum growth temperatures of 33 to $35^{\circ} \mathrm{C}$ for isolates from carnation obtained from various locations. This association is further supported by results obtained by Grisham and coworkers (12), who reported optimum growth temperatures of 32 to $33^{\circ} \mathrm{C}$ and a maximum growth temperature of $36^{\circ} \mathrm{C}$ for an isolate of $P$. parasitica from Texas, as well as by our recovery of isolates from Florida, Missouri, and Texas. Results obtained in the current study indicated that $P$. nicotianae from these areas was able to sustain nearly optimum growth rates at $35^{\circ} \mathrm{C}$ whereas growth of $P$. erythroseptica and $P$. cactorum was completely inhibited at that temperature. Pathogenicity tests conducted by Grisham and co-workers (12) demonstrated that $P$. parasitica caused the greatest amount of damage at 34 to $36^{\circ} \mathrm{C}$; therefore, the ability of $P$. nicotianae to sustain growth at these high temperatures is likely to play a significant role in disease development and severity. The warmer summers experienced by growers in the upper Great Plains in recent years may at least partially explain the emergence of $P$. nicotianae as a potato pathogen in Nebraska reported here. Additional cases of $P$. nicotianae infections are likely to be documented in the northern potato crop, and the pathogen may compose a greater proportion of the overall Phytophthora population if seasonal temperatures continue to remain above average. It is also possible that $P$. nicotianae could become a more important foliar pathogen of potato because mefenoxam is no longer being used as a foliar fungicide due to the presence of resistance to this fungicide in the $P$. infestans $(3,5)$ and $P$. erythroseptica populations (31).

Interestingly, a single case of an outbreak of a foliar disease in southern Minnesota caused by $P$. cactorum also was observed during the current study. As with P. nicotianae, infections of this fungus also were limited to irrigation wheel tracks where soil was compacted and there was standing water in the field. Early work (36) demonstrated that $P$. cactorum could cause a tuber rot of potato; however, these infections were obtained artificially by inoculation. In an extensive review of the host range of $P$. cactorum, Nienhaus (19) referenced numerous studies involving inoculations of potato resulting in pink rot symptoms. Results obtained in the current study are consistent with these observations and, for the first time, demonstrate that $P$. cactorum also is capable of infecting potato leaf tissue and that such infections can occur naturally under field conditions. Additionally, a number of other Phytophthora spp. have been reported to cause pink rot of potato. Previous myceliumbased inoculation studies showed that $P$. capsici can cause pink rot in wounded tubers $(34,35)$ but will not infect intact tuber tissue (33-35). Despite these data, $S$. tuberosum is not considered to be a host of P. capsici (8). Results of the present study confirm these earlier observations and, for the first time, demonstrate that zoospores of $P$. capsici will initiate such infections. The pathogen was unable to infect tubers through eye buds but readily infected and grew within tuber tissue wounded by abrasion. In light of these findings, supplemental studies to examine pathogenicity and aggressiveness of other isolates of $P$. cap sici and $P$. cactorum should be performed.

The development and spread of a new disease, or the resurgence of an older one, should prompt growers and researchers alike to take notice. Although currently localized and not widespread within or among potato-growing regions in the United States, the appearance of $P$. nicotianae as a potato pathogen should prompt such a reaction. Sparse sporulation and low infection efficiencies of some isolates suggest that the pathogen may not be an immediate threat to potato production. However, results reported here demonstrate that isolate aggressiveness can be highly variable and, in some instances, infection frequencies of $P$. nicotianae were comparable to those of $P$. erythroseptica or $P$. infestans. Isolates of $P$. nicotianae obtained from multiple samples of potato leaves from south Texas in May 2007 were confirmed 
to be pathogenic and highly aggressive on both foliage and tuber tissue. The growers providing these samples reported very high incidence of infection and expressed concern that their crop could become completely defoliated. Severe losses due to $P$. nicotianae-induced pink rot have been reported to occur in the high plains of Texas in the past (12).

Strategies used to manage P. erythroseptica, such as planting in well-drained soils, avoiding excessive irrigation at the end of the growing season, allowing sufficient time between vine killing and harvest to promote proper periderm development, and modifying tuber-handling procedures to reduce wounding, should provide effective control of $P$. nicotianae. Our results demonstrate that limiting tuber damage would be of utmost importance because $P$. nicotianae is most aggressive on wounded tuber tissue. This importance is compounded because wounds destroy the protective barrier provided by mefenoxam, thus reducing the fungicide's effectiveness (30). All of the isolates reported here are sensitive to mefenoxam, with sensitivities similar to isolates that have no previous exposure to the fungicide (27). Mefenoxam currently is used to control $P$. erythroseptica and, therefore, should provide effective control of $P$. nicotianae if tuber damage is kept at a minimum because wounding has been demonstrated previously to negate the tuber protection provided by mefenoxam against invasion by water rot pathogens (30).

Cultivar resistance also may be an alternative to effectively manage pink rot caused by $P$. nicotianae. It has been demonstrated previously that susceptibility to $P$. erythroseptica varies widely among commercially acceptable cultivars (23). From the studies reported here, it appears that the susceptibility of cultivars to $P$. nicotianae does not differ from that of $P$. erythroseptica. However, further studies are needed involving a greater range of cultivar susceptibilities to fully investigate the relationship of resistance to $P$. nicotianae and P. erythroseptica.

Results reported and discussed in this article should increase awareness that foliar and tuber infections caused by $P$. nicotianae can occur and that these diseases potentially could become more common. The foliar phase also may become more important because it can be confused with late blight, leading to misdiagnosis of $P$. nicotianae infections. That problem could be compounded further because both pathogens can cause foliar blight in the same field at the same time.

\section{ACKNOWLEDGMENTS}

We thank D. Peterson, R. Sherman, and V. Chapara for technical assistance; W. Kirk, Michigan State University, and R. Mulrooney, University of Delaware, for contributing some of the isolates used in these studies; J. Ristaino, North Carolina State University, for providing $P$. infestans DNA; J. Gilley and J. Ziems, CSS Farms, for their assistance; Z. Haugen and J. Nordgaard, Black Gold farms, and A. Walther and K. Ritchie, Walther Farms, for supplying field samples; and Z. Haugen (Fig. 1A, C, and D) and J. Gilley (Fig. 1B) for providing photographs of $P$. nicotianae foliar infections from the field.

\section{LITERATURE CITED}

1. Bonde, R. 1938. The occurrence of pink-rot and wilt in Maine. Plant Dis. Rep. 22:460.

2. Cairns, H., and Muskett, A. E. 1933. Pink rot of the potato. Ann. Appl. Biol. 20:381-403.

3. Davidse, L. C., Looyen, D., Turkensteen, L. J., and Van der Wal, D. 1981. Occurrence of metalaxyl-resistant strains of Phytophthora infestans in Dutch potato fields. Neth. J. Plant Pathol. 87:65-68.

4. de Icochea, T. A. 2001. Brown spot and black pit. Pages 18-19 in: Compendium of Potato Diseases, 2nd ed. W. R. Stevenson, R. Loria, G. D. Franc, and D. P. Weingartner, eds. American Phytopathological Society Press, St. Paul, MN.

5. Dowley, L. J., and O'Sullivan, E. 1981. Metalaxyl-tolerant strains of Phytophthora infestans (Mont.) De Bary in Ireland. Potato Res. 24:417-421.

6. Drechsler, C. 1929. A diplanetic species of Phytophthora causing pink rot of potato tubers. (Abstr.) Phytopathology 19:92.

7. Ersek, T., Schoelz, J. E., and English, J. T. 1994. PCR amplification of species-specific DNA sequences can distinguish among Phytophthora species. Appl. Environ. Microbiol. 60:2616-2621.

8. Erwin, D. C., and Ribeiro, O. K. 1996. Phytophthora Diseases Worldwide. American Phytopathological Society Press, St. Paul, MN.

9. Franc, G. D., and Christ, B. J. 2001. Early blight. Pages 22-23 in: Compendium of Potato Diseases, 2nd ed. W. R. Stevenson, R. Loria, G. D. Franc, and D. P. Weingartner, eds. American Phytopathological Society Press, St. Paul, MN.

10. Fry, W. E., Thurston, H. D., and Stevenson, W. R. 2001. Late blight. Pages 28-30 in: Compendium of Potato Diseases, 2nd ed. W. R. Stevenson, R. Loria, G. D. Franc, and D. P. Weingartner, eds. American Phytopathological Society Press, St. Paul, MN.

11. Goss, R. W. 1949. Pink rot of potato caused by Phytophthora erythroseptica Pethyb. Univ. Nebr-Lincoln Coll. Agric. Agric. Exp. Stn. Res. Bull. 160.

12. Grisham, M. P., Taber, R. A., and Barnes, L. W. 1983. Phytophthora rot of potatoes in Texas caused by Phytophthora parasitica and $P$. cryptogea. Plant Dis. 67:1258-1261.

13. Johnson, D. A. 1994. Effect of foliar infection caused by Colletotrichum coccodes on yield of Russet Burbank potato. Plant Dis. 78:10751078.

14. Johnson, D. A., and Miliczky, E. R. 1993. Effects of wounding and wetting duration on infection of potato foliage by Colletotrichum coccodes. Plant Dis. 77:13-17.

15. Lambert, D. H., and Salas, B. 2001. Pink rot. Pages 33-34 in: Compendium of Potato Diseases, 2nd ed. W. R. Stevenson, R. Loria, G. D. Franc, and D. P. Weingartner, eds. American Phytopathological Society Press, St. Paul, MN.

16. MacNish, G. C. 1968. Pink rot of potatoes in Western Australia. Plant Dis. Rep. 52:280.

17. Millikin, G. A., and Johnson, D. E. 1992. Oneway treatment structure in a completely randomized design with heterogeneous errors.
Pages 16-28 in: Analysis of Messy Data, Vol. 1. Designed Experiments. Chapman and Hall, London.

18. Mulrooney, R. P., Carroll, R. B., Morehart, A. L., and Wittington, D. P. 1994. Potato pink rot in Delaware and New Jersey caused by Phytophthora nicotianae. (Abstr.) Phytopathology 84:546.

19. Nienhaus, F. 1960. Das Wirtsspektrum von Phytophthora cactorum (Leb. et Cohn) Schroet. Phytopathol. Z. 38:33-68.

20. Person, L. H., and Nielsen, L. W. 1969. Potato blight caused by Phytophthora parasitica in North Carolina. (Abstr.) Phytopathology 59:117.

21. Pethybridge, G.-H. 1913. On the rotting of potato tubers by a new species of Phytophthora having a method of sexual reproduction hitherto undescribed. Sci. Proc. R. Dublin Soc. 13:529-565.

22. Rowe, R. C., and Schmitthenner, A. F. 1977. Potato pink rot in Ohio caused by Phytophthora erythroseptica and P. cryptogea. Plant Dis. Rep. 61:807-810.

23. Salas, B., Secor, G. A., Taylor, R. J., and Gudmestad, N. C. 2003. Assessment of resistance in tubers of potato cultivars to Phytophthora erythroseptica and Pythium ultimum. Plant Dis. 87:91-97.

24. Salas, B., Stack, R. W., Secor, G. A., and Gudmestad, N. C. 2000. Effect of temperature, wounding and inoculum density on the development of pink rot caused by Phytophthora erythroseptica. Plant Dis. 84:1327-1333.

25. Secor, G. A., and Gudmestad, N. C. 1999. Managing fungal diseases of potato. Can. J. Plant Pathol. 21:213-221.

26. Shaner, G., and Finney, R. E. 1977. The effect of nitrogen fertilization on the expression of slow-mildewing resistance in Knox wheat. Phytopathology 67:1051-1056.

27. Shew, D. 1985. Response of Phytophthora parasitica var. nicotianae to metalaxyl exposure. Plant Dis. 69:559-562.

28. Stamps, D. J. 1978. Phytophthora erythroseptica. Descriptions of Pathogenic Fungi and Bacteria, No. 593. Commonwealth Mycological Institute, Kew, England.

29. Taylor, R. J, Pasche, J. S., and Gudmestad, N. C. 2006 Biological significance of mefenoxam resistance in Phytophthora erythroseptica and its implications for the management of pink rot of potato. Plant Dis. 90:927-934.

30. Taylor, R. J., Salas, B., and Gudmestad, N. C. 2004. Differences in etiology affect mefenoxam efficacy and the control of pink rot and leak tuber diseases of potato. Plant Dis. 88:301-307.

31. Taylor, R. J., Salas, B., Secor, G. A., Rivera, V., and Gudmestad, N. C. 2002. Sensitivity of North American isolates of Phytophthora erythroseptica and Pythium ultimum to mefenoxam (metalaxyl). Plant Dis. 86:797-802.

32. Thompson, A. L., Taylor, R. J., Pasche, J. S., Novy, R. G., and Gudmestad, N. C. 2007. Resistance to Phytophthora erythroseptica and Pythium ultimum in a potato clone derived from S. berthaultii and S. etuberosum. Am. J. Potato Res. 84:149-160.

33. Tompkins, C. M., and Tucker, C. M. 1937. Phytophthora rot of honeydew melon. J. Agric. Res. 54:933-944.

34. Tucker, C. M. 1931. Taxonomy of the genus Phytophthora de Bary. Univ. Mo. Agric. Exp. Stn. Res. Bull. 153.

35. Wiant, J. S., and Tucker, C. M. 1940. A rot of Winter Queen watermelons caused by Phytophthora capsici. J. Agric. Res. 60:73-88.

36. Wijers, E. E. 1937. Phytophthora wilt in carnation plants. S. Afr. J. Sci. 34:194-213. 